\title{
LYVE1 Gene
}

National Cancer Institute

\section{Source}

National Cancer Institute. LYVE1 Gene. NCI Thesaurus. Code C97287.

This gene is involved in hyaluronan binding. 